\title{
Analysis on Significance of Campus Culture Activity in Political and Ideological Education of Universities
}

\author{
Yijian Zhang \\ Yongzhou Vocational Technical College, Yongzhou, 425100, China
}

Keywords: Political and ideological education of universities; Campus culture activity; Significance

\begin{abstract}
The campus culture activity reflects the ideological concept of universities, and is also an important behavior for the ideological concept of university students. The political and ideological education of universities and the campus culture activity are mutually influenced and interact with each other. The campus culture activity is significant to the political and ecological education of universities. Facing the complicated social situation, it has become an important approach for the universities in the cultivation of talents to play the role of campus culture activity, promote the implementation of political and ideological education in universities and improve the comprehensive quality of students. This paper mainly analyzes the campus culture activity in the political and ideological education of universities.
\end{abstract}

\section{Introduction}

With the progress of society and the requirements of quality-oriented education in China, the political and ideological education of universities has become an important of talent cultivation, while the method of political and ideological education is also changing continuously, and as a special method in the political and ideological education of universities, the campus culture activity plays an important role. Strengthening the political and ideological education of university students and constructing the campus culture is an important link in the university work, and before carrying out this work, it is inevitably necessary to realize the significance of political and ideological education of universities in the campus culture activity.

\section{Overview of campus culture activity}

Campus culture represents the overall appearance of a school, and each school has the campus culture conforming to its own characteristics. The campus culture represents the lifestyle of university students, mainly the material, intelligent, mental and regulated culture constituted with the promotion of the development progress of school, and also the common value concept and code of conduct of the school, and this connotation is explained from a wide perspective. From the narrow perspective, campus culture is the combination of campus culture and cultural activities, i.e. the organization and implementation of association activities, cultural and artistic activities, so as to cultivate the students' artistic sentiment and aesthetics. As an important part of the campus culture, the campus culture activity plays an important role in the campus culture.

The campus culture activities are mainly divided into the following: culture and sports activity, academic activity, social practice activity and scientific and technological activity. Through the campus culture activities, the students can display their talents. The campus culture activities are the main platform for the students to play their talents, enrich the students' spiritual life and also reflect the human spirit of the school.

\section{Significance of campus culture activity in political and ideological education of universities}

With more and more complicated environment of the society and higher institutions and the development of science and technology, the information sharing speed and scope are strengthened, and the students can obtain information from various sides, including negative information, which 
influences the politics and ideology of students. Therefore, it is the responsibilities that must be fulfilled for universities to strengthen the ideological and political education and timely correct the students' thought, so that the students will not be influenced by the negative thought. Especially, with the promotion of quality-oriented education, the cultivation of talents with both knowledge and quality has become the objective and key point for the higher education. The campus culture activity is one of the activities that the university students are willing to participate in, and as a platform of talent show, it greatly enriches the spare life of universities. More importantly, the campus activity is significant to the political and ideological education of universities, which can promote the political and ideological education, and the next is the analysis of its significance:

The ideological and political education of universities takes campus activity as the carrier

In the political and ideological education of universities, the campus culture activity is not only an important resource, but also a carrier. The main approach for the universities to carry out administrative and ideological education is to take class as the main field for teaching, but it is far from being enough to only rely on the class teaching. The campus culture activity is generally deemed as the "second class" of political and ideological education of universities. currently, there exist many problems in the political and ideological education of universities, with insufficient class teaching and low learning enthusiasm. Therefore, the political and ideological education of universities faces an important reform period, and it is the main task for the political and ideological education of universities in the recent period to transform the teaching method, closely combine theory with practice and improve the effect of political and ideological education. The campus culture activity is highly popular among the students, so in the political and ideological education, it is taken as a carrier to present the political and ideological education contents to the students, with a more significant effect compared with the dull class teaching.

Only when the students have their life and learning blended with political and ideological education can the best effect be obtained, and meanwhile, it is also required to continuously mine the education resources of political and ideological education of universities, so as to conform to the actual campus culture of the university. Promoting the political and ideological education is a principle that should be complied with in the political and ideological education of universities. Universities will carry out various campus culture activities, and the most typical is the association activity. By participating in the campus culture activities, the university students do not only display their talents, but also affect the audiences, and intangibly, the spiritual culture is conveyed to the university students. Therefore, universities should fully play the role of campus culture activities, promote their smooth implementation, convey the correct political and ideological education to the students with correct opinion guide, and meanwhile, take the cultivation of students' sentiment, construction of soul and happiness of physical and mental conditions as the main objective, so that the students can be enlightened and build a correct world concept, life concept and value concept.

\section{The improving of effect of university political and ideological education should be consolidated by campus culture activity}

Overall, the class teaching of university political and ideological education stresses theory, with a subjectivity, while the campus culture activity pays more attention to practice, with an objectivity. It is mentioned above that the university political and ideological education must combine theory with practice to obtain the best effect, so as to really realize the objective of education ideal. Practice is based on theory, while theory should be consolidated on the basis of practice. Therefore, the university political and ideological education can be more consolidated by carrying out campus culture, and it should be promoted to a deeper education field. When carrying out the campus culture activity, universities can carry out the guideline and policy of the state to the activity, and carry out campus culture activity centered on some specific themes. For example, this year is the 66th anniversary of the founding of the PRC, so in the campus culture activity, it can be taken as an activity theme to review the past 66 years of the motherland, experience the hard work of founding PRC and today's achievements, so that the students can experience the difficulty life, have a deeper realization to the leadership of CPC and always firmly believe that the road of socialism with Chinese 
characteristics is the only correct road to make the Chinese people happy, and this is also an important approach to cultivate the students' patriotic spirit.

\section{The campus culture activity needs the university political and ideological education to provide inspiration}

The campus culture activity must have a certain theme and cannot be carried out at will, but where the inspiration of the theme from? The university political and ideological education can provide an inspiration for it, for example, the World Earth Day, World Environmental Protection Day and International Olympics Day etc. Presented in the form of performance and with more vivid image and diversified culture activity forms, like speech, film playing and artistic performance, these political and ideological education contents do not only cultivate the students' thought, but also are conveyed to the students, so that the theme of the campus culture is more colorful, and this is also an important approach to construct the campus culture.

From another perspective, the regulation of campus culture activity should also be restricted by the university political and ideological education, and the campus culture activity should also be carried with the political and ideological education as the guidance, so that it is carried out in a correct direction, thus providing a better display platform for the students. Generally, the culture activity of a university is the association organized by the students, and there are also varieties of associations, like literature association, English association, fine art association, reading association, music association and dance association. When these associations are carrying out activities, it is possible to completely blend the national guideline and policy and university ideological guideline into the association activity. When major events occur to the state, each association can carry out the culture activity based on this. As a collective, each association plays the collective force and reflects the collective honor, so as to cultivate the university students' collective sense of honor. Therefore, the university political and ideological education does not only provide a rich theme for the campus culture activity, and is presented in different forms in the campus culture activity, and its education contents are also effectively conveyed to all students.

\section{Campus culture activity in the university political and ideological education has double significances}

Every coin has two sides, and an activity is also without exception. Only with a correct guide will the activity be of active significance. Of course the campus activity has such characteristics. The quality of campus culture concerns whether the university political and ideological education can be effectively carried out. Only the excellent campus culture has educational function, correctly guide the students' politics and ideology, reconstruct the students' inner world, so that the students can treat campus as their own homeland, are enlightened, continuously improve their own quality and moralities. On the contrary, if the campus culture is not so good, has a lot of negative factors, it will guide the students to a wrong ideological road, thus influencing the students' building of value concept and their behaviors and habits, and also it is not beneficial to carry out the university political and ideological activity. Especially in the current society, various new things and information appear in campus, which shock the students' ideology, a reasonable and ordered campus order plays an extremely important role to prevent the students' ideology from being influenced. With more and more importance of internet among the students' life, various adverse information and behaviors on the internet also directly influence the university students' ideology. Therefore, it is an important approach to take the campus culture as the guide in the university political and ideological education. It is a completely new approach for the universities to cultivate high-quality talents by fully playing the role of campus culture activity, an important part of campus culture , organically combining the university political and ideological education with the campus culture activity and guiding the students' ideological concept with correct guidance.

\section{Suggestions to carry out campus culture activity}

Based on the above analysis on the significance of campus culture activity in the higher political and ideological education, it can be known that carrying out campus culture activity is of significance 
to the university political and ideological education, and it also plays a double role. Therefore, promoting the campus culture activity is an issue that universities must consider earnestly.

First, the development of universities is inseparable from the construction of campus culture. Universities should construct the campus culture well and realize that there will be the ideal effect only with persistence, and meanwhile take it as an important content in the development planning of university, emphasize the construction of campus culture, support the campus culture activity and actively encourage the associations to carry out culture activity. The university leaders should watch the students' culture activity in person, and give encouragement and suggestions so as to improve the culture activity, and meanwhile, make the students feel that the university emphasizes the campus culture activity, so that they can be more devoted to the activity and play the best role in the university political and ideological education.

Second, the universities should take students as the main body when carrying out the campus culture activity, play the students' intelligence, only the student-dominate campus culture activity is beneficial for the overall development of students. It is required to create a free environment for the students and return the power to them. Teachers and universities only play a guide and assistance role, and students should play their subjective incentives, and improve innovation ability, and only this is the most important objective for the cultivation of talents in universities. The universities should make students realize their ability, build confidence, get satisfaction and find happiness in learning and life, so as to promote the comprehensive development of students' physical and mental health.

Third, correctly deal with the relation between teaching and campus culture activity. It is required to be fully aware that the two are complementary each other, and also reflect the spirit of combining theory with practice. When dealing with the relation between teaching and campus culture activity, we should not emphasize teaching while neglecting the campus culture activity, and also should not stress the campus culture activity too much while neglecting teaching. Sometimes, there must be conflict between the too, it is required to realize that only learning is the students' main task, while the campus culture activity is the supplementation of teaching, playing the role of political and ideological education.

Finally, take the cultivation of students' innovation ability as the main objective to carry out campus culture activity. On the basis of realizing the students' leading status and dealing with the relation with teaching, when carrying out the campus culture activity, it is require to take the cultivation of students' innovation ability as the main activity objective, so that the students can build the innovation awareness, fully play their innovation ability, design the activity, improve thinking ability, and have an accurate judgment when facing the complicated life and society, so as to build a correct world concept, life concept and value concept.

\section{Conclusion}

With the rapid development of society and the continuous progress of society, various ideologies and behaviors directly influence the ideological concept and action of university students. Therefore, it is a very difficult task to strengthen the university political and ideological education. In the university political and ideological education, the campus culture activity is very significant, which cannot only supplement the political and ideological education, but can also consolidate the political and ideological education in the form of practical activity, and it is also a guarantee to ensure the smooth proceeding of university political and ideological education. On the basis of fully realizing the effect of campus culture activity to the university political and ideological education, it is required to strengthen the campus culture construction, deal with the relation between campus culture activity and teaching and take the improving of students' comprehensive quality as the ultimate objective, so as to adapt to the demand of the society for talents, and this is also an important approach to promote the quality-oriented education course of China. 


\section{References}

[1] Li Jinchen, Exploration on Significance of Campus Culture in University Ideological Education, Brilliant Chapter, 2011 (20)

[2] Zhang Qi, Exploration on Practical Teaching of University Ideological and Political Courses based on the Platform of Campus Culture Activity, Journal of Ideological and Political Education, 2012(11):91-93.

[3] Chen Yongbing, Discussion on Ideological and Political Education Function of Campus Culture Activate, Heihe Journal, 2014(9):90-91.

[4] Zhang Lei, Research on Campus Culture Activity and Students' Ability Quality Cultivation, Horizon of Science and Technology, 2014(14):153-153.

[5] Zhang Nan, Liu Yansong, Research on Ideological and Political Education of Campus Culture Activity, China Education Innovation Herald, 2012(26):236-237. 